\title{
Penanganan hiperplasia fibromatosis gingiva
}

\section{Lenni Indriani Hatta}

Bagian Ilmu Material dan Teknologi Kedokteran Gigi

Fakultas Kedokteran Gigi Universitas Hasanuddin

Makassar, Indonesia

\begin{abstract}
The treatment of oral cavity abnormality with diagnosis as hyperplasia fibromatous gingival, followed by immediate partial denture was purposed to provide esthetic of hyperplasia protruded teeth. A case study was carried out to a 20 year-old female patient with protrusive mobile anterior teeth and hyperplasia of the upper and lower jaw. Excision of gingival hyperplasia was made and the insertion of immediate partial denture after extraction of mobile and protrusive upper anterior teeth. Post-surgical and insertion control were made after 24 hours, a week, and a month, and the gingival looks normally, esthetic and a better occlusion.
\end{abstract}

Key words: Hyperplasia fibromatous gingival, excision of gingival, esthetic

\begin{abstract}
ABSTRAK
Perawatan pada kelainan rongga mulut yang didiagnosis hiperplasia fibromatous gingival yang kemudian dilanjutkan dengan pemasangan gigitiruan imidiat bertujuan untuk memperbaiki estetik gigi-gigi yang mengalami protrusi akibat hiperplasia tersebut. Studi kasus dilakukan terhadap penderita perempuan berusia 20 tahun dengan kondisi gigi-gigi anterior yang protrusi serta goyang dan keadaan gingiva yang mengalami hiperplasia pada rahang atas dan rahang bawah. Perawatan yang dilakukan adalah eksisi gingiva yang mengalami hiperplasia, dan pemasangan gigitiruan imidiat setelah ekstraksi pada gigi-gigi anterior rahang atas yang protrusi dan goyang. Kontrol pascaoperasi dan insersi dilakukan setelah 24 jam, satu minggu dan satu bulan, dan terlihat keadaan gingiva yang kembali normal, serta estetik dan oklusi yang membaik.
\end{abstract}

Kata kunci: Hiperplasia fibromatous gingiva, eksisi gingiva, estetik.

Koresponden: Lenny Indriani Hatta, Bagian Ilmu Material dan Teknologi Kedokteran Gigi, Fakultas Kedokteran Gigi Universitas Hasanuddin, Jl. Perintis Kemerdekaan Km.10, Talamanrea, Makassar, Indonesia.

\section{PENDAHULUAN}

Hiperplasia adalah peningkatan ukuran sebuah organ atau bagian-bagiannya. Hal ini ditandai dengan peningkatan jumlah elemen seluler, dan organ tidak bisa berfungsi sebagaimana mestinya. ${ }^{1}$ Fibromatosis gingiva adalah suatu pembesaran fibrosis secara progresif yang jarang dari gingiva. Keadaan tersebut timbul pada masa kanak-kanak dan menjadi lebih menonjol dengan bertambahnya usia. Pembesaran itu biasanya menyeluruh tanpa radang, mengenai permukaan bukal dan lingual dari kedua rahang dengan seimbang.

Ada dua macam fibromatosis gingiva yaitu menyeluruh dan setempat. Jenis menyeluruh bernodula, batasnya tidak jelas, menunjukkan daerah-daerah pertumbuhan gingiva yang globuler yang bergabung dan akhirnya menutupi mahkota gigi-gigi. Jenis setempat kadang-kadang dijumpai, 
yaitu pertumbuhan-pertumbuhan soliter terbatas pada atap palatum dari tuberositas maksila atau gingiva lingual dari lengkung mandibula. ${ }^{2}$ Menurut penelitian lain, salah satu pemicu terjadinya pembesaran gingival adalah adanya akumulasi plak. $^{3}$

Ketidakaturan letak gigi yang parah atau protrusi yang berat pada gigi anterior akibat hiperplasia gingiva ini dapat memberikan efek psikologis yang tidak menguntungkan terutama pada pasien wanita muda. Hal ini terjadi karena kondisi tersebut memberikan tampilan yang sangat tidak menyenangkan bagi penderita. Pada kasus ini perawatan yang dilakukan adalah pengambilan jaringan yang mengalami hiperplasia dengan cara pembedahan, yaitu eksisi serta pencabutan gigi-gigi anterior rahang atas yang goyang akibat jaringan pendukungnya yaitu gingiva yang mengalami hiperplasia serta pembuatan gigitruan imidiat yang bertujuan untuk memperbaiki estetik ${ }^{4}$ dari kondisi dan posisi gigi anterior yang telah dicabut. Perawatan pasca pembedahan selanjutnya ditangani oleh ahli prostodonsi.

Penulisan makalah ini bertujuan untuk melaporkan penanganan kasus hiperplasia yang parah dan disertai dengan gigi-gigi yang goyang.

\section{LAPORAN KASUS}

Seorang perempuan, berusia 20 tahun, yang berprofesi sebagai mahasiswi datang dengan keluhan ingin memperbaiki keadaan gingivanya. Pasien pernah dioperasi dengan kasus yang sama pada umur 7 tahun. Tetapi beberapa tahun pasca operasi gingivanya kembali bertambah besar. Dari hasil anamnesis diketahui bahwa terjadinya rekurensi ini karena penderita tidak menjaga kebersihan mulutnya. Pertumbuhan gingiva yang progresif menutup hampir seluruh permukaan mahkota gigi-gigi. Terlihat pula adanya plak dan karang gigi pada seluruh gigi. Daerah yang mengalami hiperplasia ini meliputi seluruh daerah rahang atas dan rahang bawah. Selain itu, gigigigi anterior rahang atas, yaitu gigi 12, 11, 21, dan 22, malah mengalami goyang derajat 3. Pada kasus ini, direncanakan prosedur operasi yang dilakukan beberapa tahap, yaitu tahap pertama dilakukan pada regio yang dianggap paling parah dan mengganggu kenyamanan pasien, yaitu daerah anterior rahang atas. Selanjutnya, bagian posterior rahang atas dan terakhir rahang bawah. Pada daerah anterior rahang atas seluruh gingival dieksisi dan dilakukan pencabutan gigi yang goyang.

\section{Prosedur klinik}

Pada laporan kasus ini prosedur kerja yang dilakukan yaitu prosedur klinik, mulai dari pembuatan foto panoramik, pembersihan plak dan karang gigi.

Setelah serangkaian perawatan tersebut, pasien dimasukkan ke ruang operasi kemudian dilakukan anestesi umum. Pada pembedahan pertama-tama dilakukan pencabutan gigi-gigi insisivus sentralis dan insisivus lateralis, kiri dan kanan yang goyang. Selanjutnya dilakukan pengambilan gingiva yang mengalami hiperplasia pada daerah anterior rahang atas, dengan menggunakan skalpel. Setelah pembersihan bekas operasi, selanjutnya dilakukan dan kontrol perdarahan.

\section{PEMBAHASAN}

Hiperplasia atau fibromatosis gingiva merupakan gangguan gen tunggal yang sangat langka, yaitu sebuah kondisi gingiva membesar dan menutupi gigi-gigi. Jaringan yang membesar, umumnya keras dan berwarna merah mudah, dan terdiri dari pembesaran jaringan fibrosis. ${ }^{5}$ 


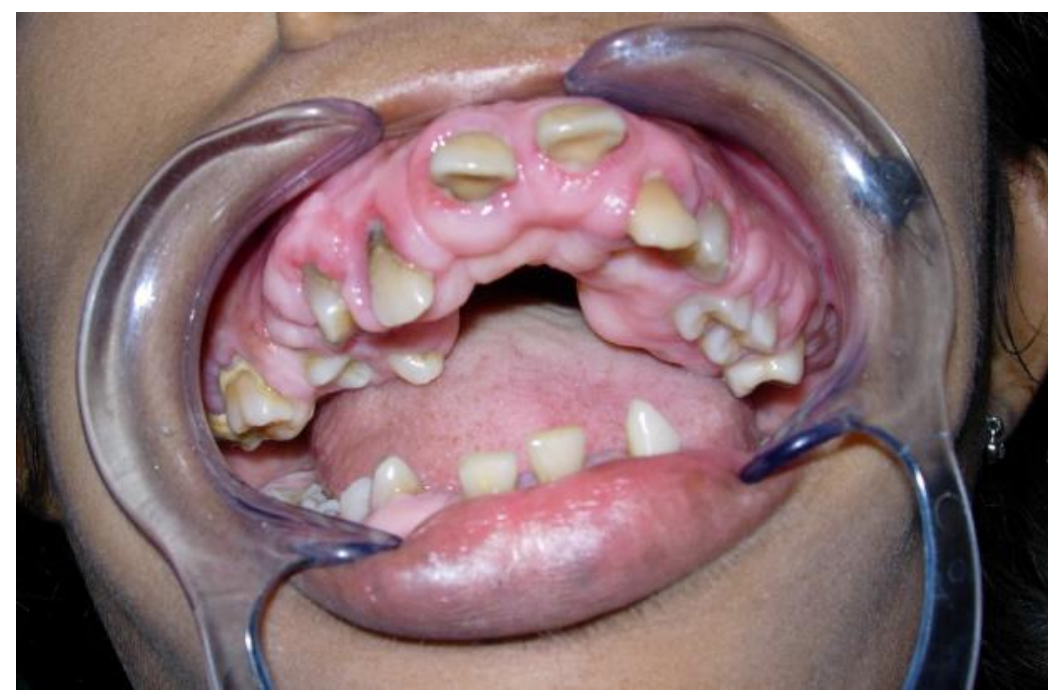

Gambar 1. Keadaan gingiva pasien dengan gigi anterior rahang atas yang protrusi

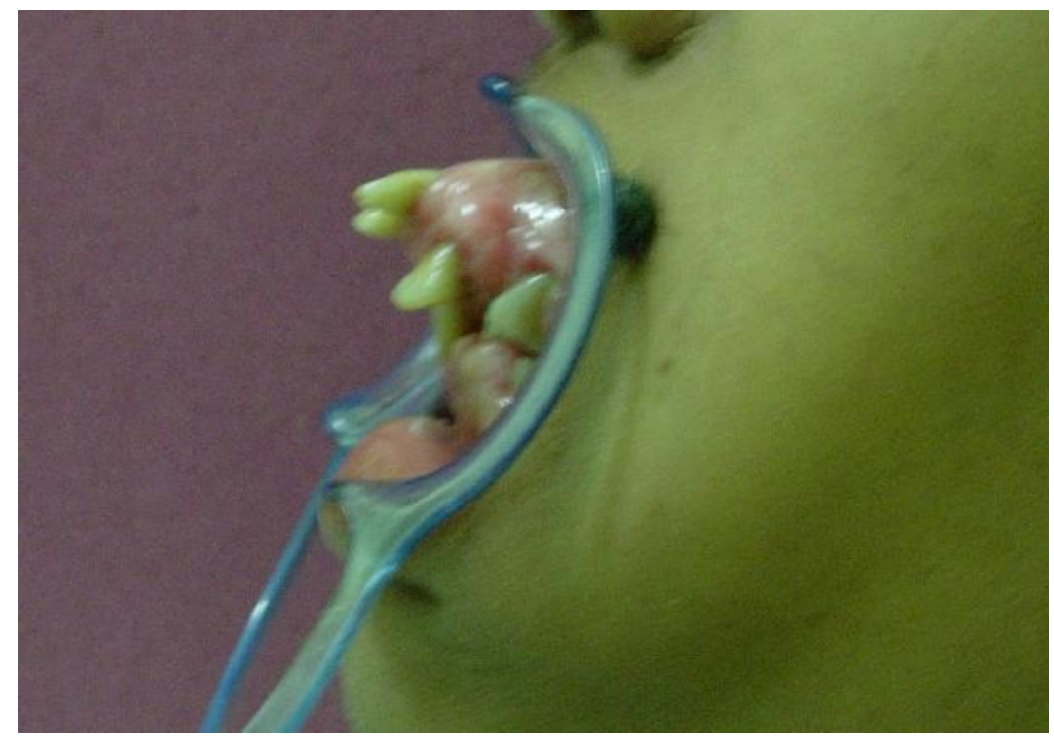

Gambar 2. Tampakan rongga mulut pasien dari samping

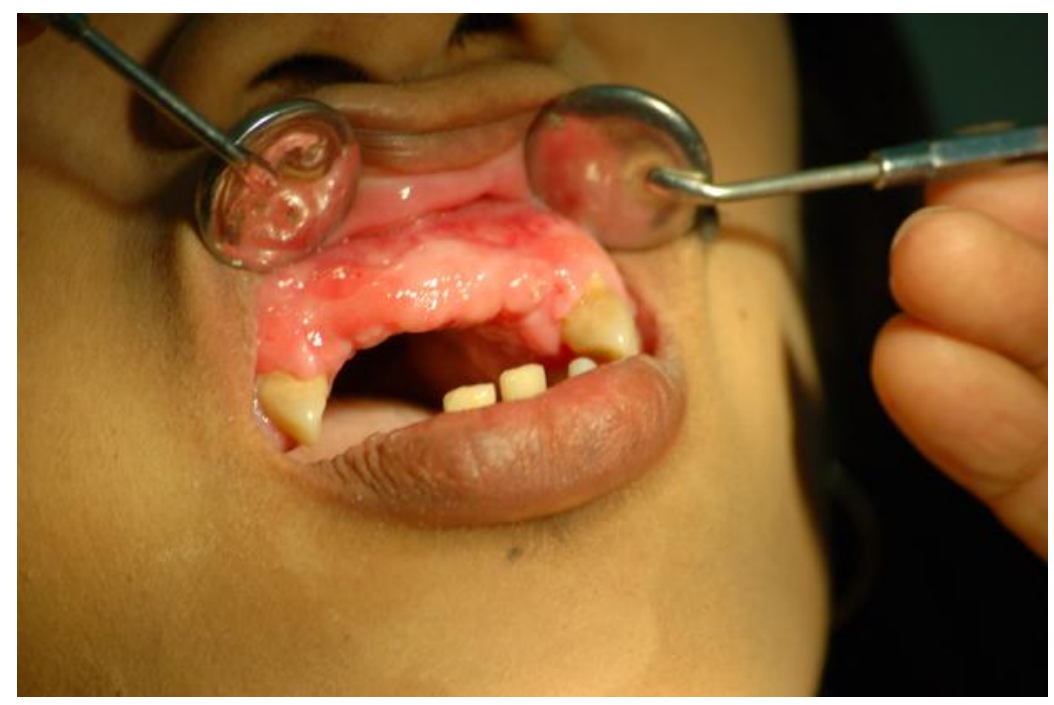

Gambar 3. Keadaan gingiva setelah dioperasi sebulan kemudian 
Pada kasus ini, terlebih dahulu dilakukan pembersihan plak dan karang gigi terlebih dahulu sebelum dilakukan perawatan lebih lanjut. Prosedur operasi dilakukan di ruang bedah, karena kondisi pasien memerlukan pembedahan. Pasien ditangani di bawah anestesi umum. Penanganan yang dilakukan pertama adalah pencabutan gigi. Gigi-gigi yang goyang dan mengalami protrusi ini akibat pembesaran gingival yang mengakibatkan tampilan yang tidak menyenangkan bagi penderita. Pada kasus ini gigi-gigi anterior rahang atas yang mengalami hiperplasia terlihat protrusi dan goyang derajat 3, sehingga harus dilakukan pencabutan pada gigi-gigi anterior rahang atas. Selanjutnya dilakukan eksisi dengan menggunakan skalpel setelah ditentukan daerah mana saja yang akan dikeluarkan. Setelah eksisi pada bagian-bagian gingiva, prosesus alveolaris yang dianggap tajam pada daerah yang terbuka, kemudian dihaluskan dan diirigasi dengan larutan salin. Irigasi larutan salin ini bertujuan untuk mengeluarkan debris, misalnya pecahan prosesus alveolaris yang dihaluskan tadi. ${ }^{6}$ Setelah itu salep topikal diaplikasikan pada daerah gingiva yang dieksisi. Salep topikal ini berguna untuk menjamin perbaikan dan re-epitalisasi yang optimal. $^{7}$

Pada kontrol 24 jam setelah operasi, keadaan jaringan belum sembuh sempurna. Selanjutnya pada kontrol pada satu minggu pasca operasi, keadaan gingiva pasien sudah membaik. Pada kontrol satu bulan pasca operasi keadaan gingiva kembali normal.

Penyembuhan jaringan gusi biasanya berlangsung sekitar 3-4 minggu, ${ }^{8}$ tetapi pada kontrol satu minggu setelah operasi, keadaan gingiva pasien menunjukkan penyembuhan yang sangat baik. Keberhasilan penyembuhan yang cepat ini karena adanya pemeliharaan secara adekuat kebersihan mulut pasien. Menurut hasil sebuah penelitian, salah satu faktor penentu keberhasilan terapi adalah frekuensi dan kecermatan dalam terapi yang dilakukan oleh dokter gigi. ${ }^{9}$

\section{SIMPULAN}

Hiperplasia fibromatosis gingival yang menyebabkan gigi-gigi anterior terlihat protrusi, mengakibatkan ketidaknyamanan pada pasien, sehingga pasien ingin memperbaiki kelainannya itu. Pemilihan perawatan yang dilakukan adalah ekstraksi gigi-gigi yang goyang akibat pembesaran gingival yang menutupi hampir semua mahkota gigi, serta eksisi daerah yang mengalami hiperplasia. Perawatan ini menguntungkan pasien, karena menghilangkan rasa tidak nyaman akibat pembesaran gingival, dan tujuan pasien untuk mengubah penampilannya dapat tercapai.

\section{DAFTAR PUSTAKA}

1. Thomas GW, Kenneth SK, Michael GN, editors. Advance in periodontic. Illinois: Quintessence Publishing Co. Inc; 1992. p.79.

2. Robert PL, Craig SM. Kelainan rongga mulut yang lazim. Alih bahasa: Susetyo B, Editor: Juwono L. Jakarta: Hipócrates; 1992. p.28-30.

3. American Academy of Periodontology. Inflamation: connecting the mouth and body. Available at: http://www.perio.org/consumer/ inflammation.htm. Diakses 17 January 2009.

4. Anderson JN, Storer R. Immediate and replacement denture. $3^{\text {rd }}$ ed. Oxford: Blackwell Scientific Publications; 1981. p.20.

5. Manson JD. Buku ajar periodonti. Alih bahasa: Anastasia S. Editor: Kentjana S. Jakarta: Hipokrates; 1993. p.76-7.

6. Hussam S, Jacob G. Surgical extractions. In: Text book manual of minor oral surgery for the general dentist. Philadelpia: W.B. Saunders; 2006. p.19-30.

7. Alam M. Basic excisional surgery. Available at http://www.emedicine.mediscape.com/ article. Diakses pada 13 Januari 2009.

8. Healing after tooth extraction and oral surgery, Dental fear central. Available at 
http://www.dentalfearcentral.org. pada 13 Januari 2009.

Diakses
9. Fedi FP, Vernino AR, Gray JL. Silabus periodonti. Alih bahasa: Amaliya. Jakarta: EGC; 2005. p.216-21. 